\title{
Dendritic cell-based COVID-19 vaccines: A mini review
}

\author{
Dewi PERTIWI ${ }^{1}$ iD, Ihsanul HAFIZ ${ }^{2 *}$ (D), Didi Nurhadi ILLIAN ${ }^{3}$ iD \\ 1 Department of Pharmaceutical Biology, Faculty of Pharmacy, Universitas Sumatera Utara, Medan 20155, Indonesia. \\ 2 Department of Pharmacology, Faculty of Pharmacy and Health, Institut Kesehatan Helvetia, Medan 20124, \\ Indonesia. \\ 3 Department of Pharmacy, Faculty of Mathematics and Natural Sciences, Universitas Syiah Kuala, Banda Aceh \\ 23111, Indonesia. \\ * Corresponding Author. E-mail: ihsanulhafiz@helvetia.ac.id (I.H.); Tel. +62-813-717 4058 (8).
}

Received: 29 May 2021 / Revised: 13 September 2021 / Accepted: 02 November 2021

\begin{abstract}
Immunotherapy is the latest approach that could offer potential treatments to help fight the 2019 coronavirus disease (COVID-19). This approach can be achieved by several strategies, including dendritic cell-based vaccine therapy. The method of using dendritic cells aims to build a person's immunity against the SARS-CoV-2 virus (the virus that causes COVID-19). In theory, this vaccine works by taking dendritic cells from a person. These cells are then introduced to the antigen of the SARS-COV-2 virus in the laboratory, then injected back into the body in the hope that the dendritic cells that have recognized the virus will trigger an immune response. Several clinical trials are being conducted using the dendritic cell-based vaccine therapy, one of the vaccine candidates known to use a dendritic cell platform developed in Indonesia. The WHO-registered dendritic cell-based COVID-19 vaccine from Indonesia was carried out by AIVITA Biomedical, the Health Research and Development Agency, and the Indonesian Ministry of Health. This article discussed how approved vaccines can trigger innate immunity to enhance long-lasting immunological memory and consider future implications for protecting populations with this vaccine.
\end{abstract}

KEYWORDS: COVID-19; dendritic cell; efficacy; safety; SARS-CoV-2; vaccine.

\section{INTRODUCTION}

At the end of 2019, the world was shocked by the emergence of a new virus that has the potential to become a global pandemic. This virus was first known to infect 4 people in Wuhan, Hubei Province, China, in December 2019 with symptoms of acute respiratory syndrome. In early January 2020, the cases increased rapidly to 830 cases. In March 2020, the virus had spread to several countries including Japan, South Korea, Taiwan, Thailand, Singapore, and the US, which the WHO declared a global pandemic. The virus that caused this global pandemic was called severe acute respiratory syndrome coronavirus-2 (SARS-CoV-2) and the disease was designated by the WHO as Coronavirus Disease 2019 (COVID-19)[1-3].

The SARS-CoV-2 virus is a sub-family of Coronaviridae, this type of virus had caused SARS and MERS in the last two decades. SARS-CoV-2 was first identified from the bronchoalveolar fluid of a COVID-19 patient in Wuhan by researchers from China. This virus is known to be $85 \%$ similar to the virus found in bats (bat-SLCoVZC45, GenBank: MG772933.1). In addition, the genome sequence results also showed $79 \%$ similarity to SARS-CoV and $50 \%$ to MERS-CoV $[1,4,5]$.

To prevent the spread of the virus and the global pandemic, various efforts have been made in various parts of the world by producing and testing vaccines. According to WHO, as of April 2021, 236 vaccines were under development. About 87 vaccine candidates have entered clinical trials, and 20 vaccine candidates have entered phase 3 clinical trials [6]. There are several types of COVID-19 vaccines currently being developed, including inactivated virus-based vaccine, DNA-based vaccine, mRNA-based vaccine, subunit protein virusbased vaccine, and viral vector-based vaccine [6,7].

Among the various types of vaccine platforms available, the Government of Indonesia, through the Indonesian Ministry of Health and Aivita Biomedical, Inc., designed a different type of vaccine, namely the dendritic cell vaccine platform. This vaccine has been clinically tested and registered on ClinicalTrials.gov on December 30, 2020 with no. NCT04690387 [6,8]. The clinical trial process of this vaccine has been obstructed by many criticisms given by researchers and health practitioners regarding its logical and safe use. This article 
will discuss the efficacy and safety of dendritic cell type vaccines in the form of criticism or narrative adapted from various articles related to the COVID-19 vaccine and dendritic cell therapy.

\section{COVID-19 VACCINES}

Currently, the COVID-19 vaccine has been implemented in various parts of the world, although no vaccines has yet completed clinical trials. Types of vaccines that have been approved for Emergency Use Authorization (EUA) from the respective country authorities include Coronavac by Sinovac, Sinopharm, Pfizer-BioNTech, AstraZeneca, Moderna, and Novavax. Commonly used vaccines have entered phase 3 clinical trials $[6,9]$.

Coronavac is a type of vaccine derived from a traditionally inactivated virus. This vaccine was developed by Sinovac Life Sciences (Beijing, China). Preclinical results indicated that this vaccine was capable of inducing a favorable antibody response in animals. Preclinical tests conducted on mice, rats, and nonhuman primates had shown partial or complete protection [10]. The results of clinical trials conducted on participants aged 18-59 years showed that the Coronavac was well tolerated and created a humoral response to SARS-CoV-2. Coronavac was also well-tolerated and developed immunogenicity in participants aged 60 years and older [11,12]. Similar vaccine candidates manufactured by Sinopharm have demonstrated that 2 doses of the vaccine are safe and well-tolerated on days 0 and days 21 until 28 [13].

The current vaccine candidate with a viral vector platform of ChAdOx1 $\mathrm{nCoV}-19$ is being developed by AstraZeneca and the University of Oxford. ChAdOx1 nCoV-19 (AZD1222) is a SARS-CoV-2 vaccine candidate comprising a replication-deficient simian adenovirus expressing the full-length SARS-CoV-2 spike protein. Safety and tolerability tests showed that $28.8 \%$ of participants experienced post-vaccination pyrexia, but there was a decrease in reactogenicity with the booster doses. In the half stage clinical trial, there were no serious side effects for the participants. The efficacy test showed an excellent immune enhancement after the vaccine administration which was characterized by interferon- $\gamma$ and tumor necrosis factor- $\alpha$ cytokine secretion by CD4+ T-cells and antibody production, especially the IgG1 and IgG3 subclasses. CD8+ T-cells, of monofunctional, polyfunctional, and cytotoxic phenotypes, were also induced [14,15]. Phase 2/3 clinical trials showed that the vaccine was better tolerated in older adults than in younger adults. Local systemic reactions (injection-spot pain, fever, muscle ache, headache) were experienced significantly more than the placebo group but were less common in participants aged 56 years or older [16]. After mass vaccination, the use of the AstraZeneca-Oxford vaccine resulted in blood clots as a side effects. The results of the EU and UK investigations suggested that this side effect is possible but very rare, with a ratio of 79 cases out of 20 million participants $(0.0004 \%)$. From 79 cases of blood clots, about 19 people were dead $[17,18]$. Similar thing happened to the Johnson \& Johnson vaccine. There were 6 cases out of 7 million participants who were vaccinated, which made US regulators temporarily suspended the use of this vaccine $[19,20]$.

Vaccines that have high effectiveness (>90\%) are Pfizer-BioNtech and Moderna. Both vaccines are mRNA-based vaccine. The vaccine candidates produced by Pfizer-BioNtech, called BNT162b1 and BNT162b2, are nucleoside-modified mRNA formulated by lipids nanoparticle encoding the receptor-binding domain (RBD) of the SARS-CoV-2 spike protein. Based on the half phase clinical trial, several mechanisms were beneficial in providing protection against COVID-19 and mild-moderate local to systemic reactogenicity depending on the number of doses administered [21,22]. Comparison of the efficacy and safety of the two vaccine candidates showed that BNT162b2 had a lower incidence. The effectiveness of BNT162b2 in preventing COVID-19 is $15 \%$ (credible interval 90.3 to $97.6 \%$ ). Safety reaction after the BNT162b2 vaccine is characterized by short-term mild to moderate pain at the injection spot, fatigue, and headache. The incidence of serious side effects was lower, similar to the placebo group [23,24].

The mRNA-1273 vaccine candidate (Moderna and National Institute of Allergy and Infectious Disease) in phase 2 clinical trials produced a significant immune response with a well-accepted safety profile after administration of a 2-dose regimen. The efficacy value of this vaccine was $94.1 \%$ ( 89.3 to $96.8 \%$ ). Clinical trial participants given mRNA-1273 had higher reactogenicity than placebo, but serious side effects were rare in the vaccine or placebo group. The side effect reactions felt by the participants were headache, fatigue, myalgia, arthralgia, nausea, and vomiting $[25,26]$.

One of the subunit-based vaccine platforms was developed by Novavax with recombinant acute respiratory syndrome coronavirus 2 (SARS-CoV-2) nanoparticle vaccine composed of trimeric full-length SARS-CoV-2 spike glycoproteins and formulated Matrix-M1 adjuvant (NVX-CoV2373). In preclinical trials against Macaca fascicularis, administration of NVX-CoV2373 provided protection by inducing anti-S antibodies and blocking binding to the angiotensin-converting enzyme 2 (hACE2) receptor. Phase 1-2 clinical trials 
showed that NVX-CoV2373 was acceptable without mild reactogenicity, had no symptoms of severe side effects in each participant, and had good efficacy in triggering the immune system $[27,28]$.

In addition to the vaccine candidates above, vaccines that have entered phase 3 were developed by the Center for Genetic Engineering and Biotechnology (CIGB), Sanofi Pasteur and GSK, Bharat Biotech International Ltd., Zydus Cadila, Research Institute for Biological Safety Problem Republic of Kazakhstan, Institute of Medical Biology and Chinese Academy of Medical Sciences, CureVac AG, and Anhui Zhifei Longcom Biopharmaceutical and Chinese Academy of Sciences.

\section{DENDRITIC CELLS}

Dendritic cells (DCs) are derived from CD34+ bone marrow progenitor cells (CD4+ monocytes) that present antigens with unique abilities and are capable of inducing a primary immune response [29]. DCs are located in 2 types of locations in the body; non-lymphoid tissues such as skin, mucosa, and internal organs, and are also found in lymphoid organs, blood, and afferent lymphatic vessels. DCs are capable of capturing and transferring information from the outside into adaptive immune cells. B-cells and T-lymphocytes are immunity mediators controlled by dendrite cells. Peripheral dendritic cells capture and process antigens, express lymphocyte co-stimulating molecules, migrate to lymphoid organs and secrete cytokines to initiate immune responses. Apart from being able to induce primary immunity, DCs are also important in immune tolerance and regulation of immune response by tolerating T-cells against innate body antigens (self-antigens), thereby minimizing autoimmune reactions. Currently, DCs-based immunotherapy is used to gain immunity against cancer and infectious diseases [30,31].

Host defense depends on the joint action of innate immunity with nonspecific antigens and adaptive immunity against specific antigens. Innate immunity includes phagocytic cells, Natural Killer (NK) Cells, complement, and Interferons (IFNs). Innate immunity uses a variety of recognition receptors to identify various pathogens such as bacterial liposaccharides (LPS), carbohydrates, and double-stranded viral RNA. In addition to recognizing pathogens, innate immunity functions to provide signals to adaptive immune cells to form a large diversity of antigen-specific clones and immunological memory [30].

The life cycle of dendritic cells begins with the circulation of dendritic precursor cells and enters the tissue as immature dendritic cells. Immature dendritic cells can directly capture pathogens (eg viruses) that cause the secretion of cytokines (eg IFNa), and then activate eosinophils, macrophages, and NK-cells. Dendritic cells that have captured antigens migrate to the lymphoid organs and turn immature cells into mature cells which then release antigen-specific lymphocytes. Activated T-cells help dendritic cells in the maturation process which ultimately results in their expansion and differentiation into active, helper, and cytotoxic T-lymphocytes. Activated T-cells can move towards damaged tissue, and helper T-cells help release cytokines which then allow activation of macrophages, NK-cells, and eosinophils. T-cytotoxic cells lyse infected cells. Dendritic cells that have matured simultaneously with T-cells activate B-cells and then migrate to various areas, which eventually become plasma cells that produce antibodies. Mature dendritic cells that interact with lymphocytes will die or undergo apoptosis to prevent autoimmune events [31,32].

The process of forming various types of DCs starts from hematopoietic stem cell (HSC), located in the bone marrow, which turn into a common myeloid progenitor (CMP) and then into a granulocyte-macrophage progenitor (GMP), and become a macrophage DC precursor (MDP) and finally become a common DC precursor (CDP). It is known that the types of CDP are CD34+, HLA-DR+, CD123+, and Lin-. GMP, apart from turning into MDP, can also become a common monocyte progenitor (cMoP), which then differentiates monocytes and tissue into inflammatory DC and inflammatory macrophage cells. The CDP then differentiated into pre-DC (CD34-, CD123+, CD33+ and CD2+), and immature $\mathrm{pDC}(\mathrm{CD} 2+)$. The pre-DC transform into early pre-classical DC (pre-cDC) then differentiate into pre-cDC1 and pre-cDC2 which circulate in the blood and upon entering the network, it changes into classical DC ( $\mathrm{CDC1}$ and $\mathrm{cDC} 2)$. CDP in the other path changes to immature plasmacytoid DC ( $\mathrm{pDC}$ ) residing in tissues. It is known that three main subpopulations of DC reside in major lymphohematopoietic organs, including blood, lymph, thymus, tonsils, bone marrow, and blood vessel. The pDCs constitute the majority of DCs in the thymus and tonsils, subtypes CD1c and CDC2s mostly circulate in the blood, vein, bone marrow, and spleen. The subpopulations of DCs circulating in non-lymphoid tissues include $\mathrm{cDC} 1 \mathrm{~s}, \mathrm{cDC} 2$, and pDCs $[33,34]$.

Immunologically, dendritic cells are the link between innate immunity and adaptive immunity in response to tumors in the body. DC Precursors are able to recognize Pathogen Associated Molecular Patterns (PAMPs) through their Pattern Recognition Receptors (PRRs). The response given to this interaction is the release of interferon (IFN), which then activates macrophages (MF) and natural killer (NK) T-Cells. NK-cells 
will kill the tumor and release the tumor cell body. The detached tumor cell bodies will be captured by immature dendritic cells, then the cell maturation process occurs. Afterwards, mature cells possessing antigens lead to the selection of tumor-specific lymphocyte release, including CD8+ T-cells and CD4 T-cells. The resulting CD8+ is functional and can kill tumors directly, and CD4 T-cells help activate macrophages, NKcells, and eosinophils [30].

Dendritic cells also have a very important role in the body's defense system against microbes, parasites, and viruses attack. Microbes that produce lipopolysaccharide (LPS) and CpG DNA are able to activate innate immune mechanisms including DC which then provide further defense responses to the body. DCs activated by bacterial invasion will undergo maturation through the ERK Kinase pathway and increase expression of class II MHC co-stimulators, the release of chemokines, and migration. This coordinated process will stimulate the release of IL-12 and induce an immune response [30].

In response to invasion by pathogenic parasites such as Leishmania, immature DC phagocytize parasitic organisms and Langerhans Cells (LCs) that have been infected by these parasites. Other parasites such as Toxoplasma gondii can induce and redistribute DC to the T-cells areas and activate IL-12. Parasites have their own defense systems to anticipate the immune system triggered by DCs. For example, Plasmodium falciparum invasion that infects erythrocyte and then attaches to DC will result in inhibited DC maturation which ultimately does not release T-cells as a form of body defense [30].

Viral infection can affect DC in pathogenesis/immune response. Various viruses such as cytomegalovirus (CMV), human immunodeficiency virus (HIV), measles, herpes, and influenza are able to interfere with DC performance through various mechanisms. These include viruses that are distributed throughout the entire body surface with the help of DC which is able to provide a means of accessing other cells. Viruses are persistently induced to DCs and impair DC function and bypass immune surveillance (e.g. CMV and HIV). DCs are susceptible to the cytopathic effects of viruses (e.g. measles and HIV), doublestranded viruses can induce DC maturation and re resistant to viral cytopathic effects of viruses. The acquisition of viral antigens (Ags) by DCs may occur through the capture of virus-infected apoptotic cells, as for influenza, expression of receptors such as for HIV, where DCs express both CD4, the receptor for HIV, and chemokine receptors acting as co-receptors for HIV. Positive DC response in providing antiviral response by triggering the development of non-clonal and specific Ag. The interaction of blood precursor DC (CD11c1) with virus causes the release of IFN- $\alpha$ and triggers an antiviral cascade mediated through direct and indirect cytotoxic (NK-Cells and Macrophages) [30]. For coronaviruses such as SARS-CoV and SARS-CoV-2, the primary determinant of the tropism is the $\mathrm{S}$ protein, which binds to membrane receptors expressed on host cells. Evidence of ACE2 expression by dendritic cells, particularly interstitial lung dendritic cells, suggests that dendritic cells can be infected by SARS-CoV-2 [35,36].

The immune response to viral infection depends on the rapid activation of PPRs expressed by the host cells. In response to coronavirus infection, Tol Like Receptor (TLR) 7 is activated by single-stranded RNA in endosome. Retinoic acid-inducible gene I (RIG-I) and melanoma differentiation-associated gene 5 (MDA-5), which recognize double-stranded cytosolic viral RNA containing a 50-triphosphate group, and/or lack of a 50-methyl cap, as well as cytosol DNA activates cyclic GMP-AMP synthase as stimulator of the interferon gene pathway $[35,37,38]$. The activation of these PRRs initiates downstream signaling cascades such as interferon response factor (IRF3), IRF7, and nuclear factor-kappa B (NF-kB), followed by their nuclear translocation. In the nucleus, these transcription factors induce the expression of type I interferons (IFNs; IFN-a, and IFN-b) and other pro-inflammatory cytokines. Type I IFNs promotes a strong anti-viral response that limits viral replication at an early stage $[39,40]$.

\section{SAFETY AND EFFICACY OF DENDRITIC CELLS BASED VACCINE}

The unique characteristics of dendritic cells make them an option for the development of vaccines that have been carried out against tumors and other pathogens. A dendritic cell-based vaccine against SARS-CoV2 is currently being developed [35]. Among various COVID-19 vaccine platforms, the Indonesian Ministry of Health and Aivita Biomedical Inc. developed a viral vector platform (replica) + Antigen Presenting Cells (APC), a vaccine consisting of autologous dendritic cells loaded with antigens from SARS-CoV-2, with or without Granulocyte-Macrophage Colony Stimulating Factor (GM-CSF). The developed vaccine has entered phase 1 clinical trials (NCT04690387). Phase 1 clinical trials conducted by giving autologous dendritic cells which was previously incubated with SAR-CoV-2 spike, divided into 9 type formulas, namely dendritic cells which was previously incubated with $0.1,0.33$, and $1.0 \mathrm{mg}$ antigen without GM-SCF, $0.1 \mathrm{mg}$ antigen +250 mcg GM-SCF, $0.33 \mathrm{mg}$ antigen + $250 \mathrm{mcg}$ GM-SCF, $1.0 \mathrm{mg}$ antigen + $250 \mathrm{mcg}$ GM-SCF, $0.1 \mathrm{mg}$ antigen + 500 
mcg GM-SCF, $0.33 \mathrm{mg}$ antigen +500 mcg GM-SCF, and $1.0 \mathrm{mg}$ antigen $+500 \mathrm{mcg}$ GM-SCF. Phase 1 clinical trials were expected to obtain data on the incidence of adverse event and severity in all treatments, measurement of antibodies in subjects' blood, and duration of antibodies detection against SARS-CoV-2. In phase I-II (NCT04386252), clinical trials were conducted to obtain confirmation of the vaccine used in a 1-year condition, suggested efficacy, and optimal dose. So far, the results of the research from the clinical trials had not been included. The research was estimated to be completed in March 2021 [8,41].

Antigen-presenting cells (APC) are an important component of the immune system against vaccines. Loading antigen-presenting cells with peptides that are supposed to be produced by vaccination bypasses the first steps after vaccination. The vaccination process on this platform was carried out using traditional and individual harvesting of dendritic cells, then these cells were developed and manipulated to present the desired antigen. Dendritic cells that already contain the antigen will be inserted back into the body of the same individual. When viewed from this process, the safety of the vaccine used will be very high because it is individual and has a very specific suitability so it can minimize the occurrence of unwanted reactions. On the other hand, if this concept is changed into the basis for widespread use of vaccines, it has the potential to increase the risk of rejection by the body's defense system and trigger the possibility of unexpected effects, thus the safety value of the vaccine use will be reduced. To assess whether this dendritic cell-based vaccine is effective or not, it is necessary to wait for the results of clinical trials. Despite the safety and efficacy issues, the development and trials process of this vaccine is very expensive, because it is individualized and will be difficult to use and accept in the mass vaccination process to prevent the spread of the disease [35,42].

Some of the main obstacles in the development of this vaccine include the selection of optimal target antigens that will activate T-cells and immune-specific potential. Moreover, these barriers to the development of dendritic cell-based vaccines will face the same barriers that limit vaccine development for tumors [35]. The use of the DC-vaccine therapeutic approach in cancer patients has been shown to be beneficial in treating cancer through its antitumor immune mechanisms, which can be further augmented when co-administrated with other interventions or adjuvants. It is hoped that more preclinical and clinical trials exploring different strategies and combinations will yield to better results in the development of dendrite cell-based vaccines for both cancer and COVID-19 [43].

\section{LIMITATIONS}

The dendritic cell-based vaccine for COVID-19 is still under clinical trials, and no final results obtained. Moreover, there is an immense number of theories and potential treatments for COVID-19 that are evolving every day upon verifying new evidence.

Acknowledgements: We thank Prof. Mohammad Basyuni, Prof. Urip Harahap, Prof. Rosidah for their motivation and acknowledge to research and community service, Institut Kesehatan Helvetia, Faculty of Pharmacy, Universitas Sumatera Utara and Universitas Syiah Kuala.

Author contributions: Concept - I.H.; Design - D.P., I.H., D.N.I.; Supervision - I.H.; Resources - D.P., D.N.I; Data Collection and/or Processing - I.H., D.P., D.N.I.; Analysis and/or Interpretation - I.H.; Literature Search - D.N.I., D.P.; Writing - I.H.; Critical Reviews - I.H., D.P.,D.N.I.

Conflict of interest statement: The authors declare that there are no conflicts of interest.

\section{REFERENCES}

[1] Hu B, Guo H, Zhou P, Shi ZL. Characteristics of SARS-CoV-2 and COVID-19. Nat Rev Microbiol. 2021; 19: 141-154. [CrossRef]

[2] Nishiura H, Jung SM, Linton NM, Kinoshita R, Yang Y, Hayashi K, Kobayashi T, Yuan B, Akhmetzhanov AR. The extent of transmission of novel coronavirus in Wuhan, China, 2020.J Clin Med.2020; 9(330): 1-5. [CrossRef]

[3] Baloch S, Baloch MA, Zheng T, Pei X. The coronavirus disease 2019 (COVID-19) pandemic. Tohoku J Exp Med. 2020; 250(4): 271-278. [CrossRef]

[4] Zhu N, Zhang D, Wang W, Li X, Yang B, Song J, Zhao X, Huang B, Shi W, Lu R, Niu P, Zhan F, Ma X, Wang D, Xu W, Wu G, Gao GF, Tan W; China Novel Coronavirus Investigating and Research Team. A novel coronavirus from patients with pneumonia in china, 2019. N Engl J Med. 2020; 382(8): 727-733. [CrossRef]

[5] Kim D, Lee JY, Yang JS, Kim JW, Kim VN, Chang H. The architecture of SARS-CoV-2 transcriptome. Cell. 2020; 181: 
914-921. [CrossRef]

[6] WHODraft landscape and tracker of COVID-19 candidate vaccines 2021. https://www.who.int/publications/m/item/draft-landscape-of-covid-19-candidate-vaccines, (accessed on 21 May 2021).

[7] Ashraf MU, Kim Y, Kumar S, Seo D, Ashraf M, Bae YS. COVID-19 vaccines (revisited) and oral-mucosal vector system as a potential vaccine platform. Vaccines. 2021; 9(171): 1-24. [CrossRef]

[8] ClinicalTrials.gov Dendritic cell vaccine, AV-COVID-19, to prevent COVID-19 infection 2021.https://www.clinicaltrials.gov/ct2/show/NCT04690387, (accessed on 19 May 2021).

[9] Zhang C, Zhou C, Shi L, Liu G. Perspectives on development of vaccines against severe acute respiratory syndrome coronavirus 2 (SARS-CoV-2). Hum. Vaccines Immunother. 2020; 16(10): 2366-2369. [CrossRef]

[10] Gao Q, Bao L, Mao H, Wang L, Xu K, Yang M, Li Y, Zhu L, Wang N, Lv Z, Gao H, Ge X, Kan B, Hu Y, Liu J, Cai F, Jiang D, Yin Y, Qin C, Li J, Gong X, Lou X, Shi W, Wu D, Zhang H, Zhu L, Deng W, Li Y, Lu J, Li C, Wang X, Yin W, Zhang Y, Qin C. Development of an inactivated vaccine candidate for SARS-CoV-2. Science. 2020; 369(6499): 77-81. [CrossRef]

[11] Wu Z, Hu Y, Xu M, Chen Z, Yang W, Jiang Z, Li M, Jin H, Cui G, Chen P, Wang L, Zhao G, Ding Y, Zhao Y, Yin W. Safety, tolerability, and immunogenicity of an inactivated SARS-CoV-2 vaccine (CoronaVac) in healthy adults aged 60 years and older: a randomised, double-blind, placebo-controlled, phase 1/2 clinical trial. Lancet Infect Dis. 2021; 21(6): 803-12. [CrossRef]

[12] Zhang Y, Zeng G, Pan H, Li C, Hu Y, Chu K, Han W, Chen Z, Tang R, Yin W, Chen X, Hu Y, Liu X, Jiang C, Li J, Yang M, Song Y, Wang X, Gao Q, Zhu F. Safety, tolerability, and immunogenicity of an inactivated SARS-CoV-2 vaccine in healthy adults aged 18-59 years: a randomised, double-blind, placebo-controlled, phase $1 / 2$ clinical trial. Lancet Infect Dis.2021; 21(2): 181-92. [CrossRef]

[13] Xia S, Zhang Y, Wang Y, Wang H, Yang Y, Gao GF, Tan W, Wu G, Xu M, Lou Z, Huang W, Xu W, Huang B, Wang H, Wang W, Zhang W, Li N, Xie Z, Ding L, You W, Zhao Y, Yang X, Liu Y, Wang Q, Huang L, Yang Y, Xu G, Luo B, Wang W, Liu P, Guo W, Yang X. Safety and immunogenicity of an inactivated SARS-CoV-2 vaccine, BBIBP-CorV: a randomised, double-blind, placebo-controlled, phase 1/2 trial. Lancet Infect Dis. 2021; 21(1): 39-51. [CrossRef]

[14] Barrett JR, Belij-Rammerstorfer S, Dold C, Ewer KJ, Folegatti PM, Gilbride C, Halkerston R, Hill J, Jenkin D, Stockdale L, Verheul MK, Aley PK, Angus B, Bellamy D, Berrie E, Bibi S, Bittaye M, Carroll MW, Cavell B, Clutterbuck EA, Edwards N, Flaxman A, Fuskova M, Gorringe A, Hallis B, Kerridge S, Lawrie AM, Linder A, Liu X, Madhavan M, Makinson R, Mellors J, Minassian A, Moore M, Mujadidi Y, Plested E, Poulton I, Ramasamy MN, Robinson H, Rollier CS, Song R, Snape MD, Tarrant R, Taylor S, Thomas KM, Voysey M, Watson MEE, Wright D, Douglas AD, Green CM, Hill AVS, Lambe T, Gilbert S, Pollard AJ; Oxford COVID Vaccine Trial Group. Phase 1/2 trial of SARS-CoV-2 vaccine ChAdOx1 nCoV-19 with a booster dose induces multifunctional antibody responses. Nat Med. 2021; 27: 279_ 288. [CrossRef]

[15] Ewer KJ, Barrett JR, Belij-Rammerstorfer S, Sharpe H, Makinson R, Morter R, Flaxman A, Wright D, Bellamy D, Bittaye M, Dold C, Provine NM, Aboagye J, Fowler J, Silk SE, Alderson J, Aley PK, Angus B, Berrie E, Bibi S, Cicconi P, Clutterbuck EA, Chelysheva I, Folegatti PM, Fuskova M, Green CM, Jenkin D, Kerridge S, Lawrie A, Minassian AM, Moore M, Mujadidi Y, Plested E, Poulton I, Ramasamy MN, Robinson H, Song R, Snape MD, Tarrant R, Voysey M, Watson MEE, Douglas AD, Hill AVS, Gilbert SC, Pollard AJ, Lambe T; Oxford COVID Vaccine Trial Group. T cell and antibody responses induced by a single dose of ChAdOx1 nCoV-19 (AZD1222) vaccine in a phase 1/2 clinical trial. Nat Med. 2021; 27: 270-278. [CrossRef]

[16] Ramasamy MN, Minassian AM, Ewer KJ, Flaxman AL, Folegatti PM, Owens DR, Voysey M, Aley PK, Angus B, Babbage G, Belij-Rammerstorfer S, Berry L, Bibi S, Bittaye M, Cathie K, Chappell H, Charlton S, Cicconi P, Clutterbuck EA, Colin-Jones R, Dold C, Emary KRW, Fedosyuk S, Fuskova M, Gbesemete D, Green C, Hallis B, Hou MM, Jenkin D, Joe CCD, Kelly EJ, Kerridge S, Lawrie AM, Lelliott A, Lwin MN, Makinson R, Marchevsky NG, Mujadidi Y, Munro APS, Pacurar M, Plested E, Rand J, Rawlinson T, Rhead S, Robinson H, Ritchie AJ, Ross-Russell AL, Saich S, Singh N, Smith CC, Snape MD, Song R, Tarrant R, Themistocleous Y, Thomas KM, Villafana TL, Warren SC, Watson MEE, Douglas AD, Hill AVS, Lambe T, Gilbert SC, Faust SN, Pollard AJ; Oxford COVID Vaccine Trial Group. Safety and immunogenicity of ChAdOx1 nCoV-19 vaccine administered in a prime-boost regimen in young and old adults (COV002): a single-blind, randomised, controlled, phase 2/3 trial. Lancet. 2020; 396(10267): 1979-1993. [CrossRef]

[17] Mahase E. AstraZeneca vaccine: blood clots are 'extremely rare' and benefits outweigh risks, regulators conclude. BMJ. 2021; 373: 931. [CrossRef]

[18] Wise J. Covid-19: European countries suspend use of Oxford-AstraZeneca vaccine after reports of blood clots. BMJ. 2021; 372: 699. [CrossRef] 
[19] Ledford H. COVID vaccines and blood clots: fivekey questions. Nature. 2021; 592: 495-496. [CrossRef]

[20] MacNeil JR, Su JR, Broder KR, Guh AY, Gargano JW, Wallace M, et al. Updated recommendations from the advisory committee on immunization practices for use of the janssen (Johnson \& Johnson) COVID-19 vaccine after reports of thrombosis with thrombocytopenia syndrome among vaccine recipients - United States, April 2021. MMWR. 2021; 70(17): 651-656. [CrossRef]

[21] Sahin U, Muik A, Derhovanessian E, Vogler I, Kranz LM, Vormehr M, Baum A, Pascal K, Quandt J, Maurus D, Brachtendorf S, Lörks V, Sikorski J, Hilker R, Becker D, Eller AK, Grützner J, Boesler C, Rosenbaum C, Kühnle MC, Luxemburger U, Kemmer-Brück A, Langer D, Bexon M, Bolte S, Karikó K, Palanche T, Fischer B, Schultz A, Shi PY, Fontes-Garfias C, Perez JL, Swanson KA, Loschko J, Scully IL, Cutler M, Kalina W, Kyratsous CA, Cooper D, Dormitzer PR, Jansen KU, Türeci Ö. COVID-19 vaccine BNT162b1 elicits human antibody and TH1 T cell responses. Nature. 2020; 586(7830): 594-599. [CrossRef]

[22] Mulligan MJ, Lyke KE, Kitchin N, Absalon J, Gurtman A, Lockhart S, Neuzil K, Raabe V, Bailey R, Swanson KA, Li P, Koury K, Kalina W, Cooper D, Fontes-Garfias C, Shi PY, Türeci Ö, Tompkins KR, Walsh EE, Frenck R, Falsey AR, Dormitzer PR, Gruber WC, Şahin U, Jansen KU. Phase I/II study of COVID-19 RNA vaccine BNT162b1 in adults. Nature. 2020; 586(7830): 589-593. [CrossRef]

[23] Thomas SJ, Moreira ED Jr, Kitchin N, Absalon J, Gurtman A, Lockhart S, Perez JL, Pérez Marc G, Polack FP, Zerbini C, Bailey R, Swanson KA, Xu X, Roychoudhury S, Koury K, Bouguermouh S, Kalina WV, Cooper D, Frenck RW Jr, Hammitt LL, Türeci Ö, Nell H, Schaefer A, Ünal S, Yang Q, Liberator P, Tresnan DB, Mather S, Dormitzer PR, Şahin U, Gruber WC, Jansen KU; C4591001 Clinical Trial Group. Safety and efficacy of the BNT162b2 mRNA Covid-19 vaccine. N Engl J Med. 2020; 383(27): 2603-2615. [CrossRef]

[24] Walsh EE, Frenck RW Jr, Falsey AR, Kitchin N, Absalon J, Gurtman A, Lockhart S, Neuzil K, Mulligan MJ, Bailey R, Swanson KA, Li P, Koury K, Kalina W, Cooper D, Fontes-Garfias C, Shi PY, Türeci Ö, Tompkins KR, Lyke KE, Raabe V, Dormitzer PR, Jansen KU, Şahin U, Gruber WC. Safety and immunogenicity of two RNA-Based Covid-19 vaccine candidates. N Engl J Med. 2020; 383(25): 2439-2450. [CrossRef]

[25] Chu L, McPhee R, Huang W, Bennett H, Pajon R, Nestorova B, Leav B; mRNA-1273 Study Group. preliminary report of a randomized controlled phase 2 trial of the safety and immunogenicity of mRNA-1273 SARS-CoV-2 vaccine. Vaccine. 2021; 39(20): 2791-2799. [CrossRef]

[26] Baden LR, El Sahly HM, Essink B, Kotloff K, Frey S, Novak R, Diemert D, Spector SA, Rouphael N, Creech CB, McGettigan J, Khetan S, Segall N, Solis J, Brosz A, Fierro C, Schwartz H, Neuzil K, Corey L, Gilbert P, Janes H, Follmann D, Marovich M, Mascola J, Polakowski L, Ledgerwood J, Graham BS, Bennett H, Pajon R, Knightly C, Leav B, Deng W, Zhou H, Han S, Ivarsson M, Miller J, Zaks T; COVE Study Group. Efficacy and Safety of the mRNA-1273 SARS-CoV-2 Vaccine. N Engl J Med. 2021; 384(5): 403-416. [CrossRef]

[27] Guebre-Xabier M, Patel N, Tian JH, Zhou B, Maciejewski S, Lam K, Portnoff AD, Massare MJ, Frieman MB, Piedra PA, Ellingsworth L, Glenn G, Smith G. NVX-CoV2373 vaccine protects cynomolgus macaque upper and lower airways against SARS-CoV-2 challenge. Vaccine. 2020; 38(50): 7892-7896. [CrossRef]

[28] Keech C, Albert G, Cho I, Robertson A, Reed P, Neal S, Plested JS, Zhu M, Cloney-Clark S, Zhou H, Smith G, Patel N, Frieman MB, Haupt RE, Logue J, McGrath M, Weston S, Piedra PA, Desai C, Callahan K, Lewis M, Price-Abbott P, Formica N, Shinde V, Fries L, Lickliter JD, Griffin P, Wilkinson B, Glenn GM. Phase 1-2 trial of a SARS-CoV-2 recombinant spike protein nanoparticle vaccine. NEnglJMed. 2020; 383(24): 2320-2332. [CrossRef]

[29] Berges C, Naujokat C, Tinapp S, Wieczorek H, Höh A, Sadeghi M, Opelz G, Daniel V. A cell line model for the differentiation of human dendritic cells. Biochem Biophys Res Commun. 2005; 333(3): 896-907. [CrossRef]

[30] Banchereau J, Briere F, Caux C, Davoust J, Lebecque S, Liu YJ, Pulendran B, Palucka K. Immunobiology of dendritic cells. Annu Rev Immunol. 2000; 18: 767-811. [CrossRef]

[31] Banchereau J, Steinman RM. Dendritic cells and the control of immunity. Nature. 1998; 392(6673): 245-252. [CrossRef]

[32] Granucci F, Zanoni I. The dendritic cell life cycle. Cell Cycle. 2009; 8(23): 3816-3821. [CrossRef]

[33] Schultze JL, Aschenbrenner AC. Systems immunology allows a new view on human dendritic cells. Semin Cell Dev Biol. 2018; 86: 15-23. [CrossRef]

[34] Patel AA, Ginhoux F, Yona S. Monocytes, macrophages, dendritic cells and neutrophils: an update on lifespan kinetics in health and disease. Immunology. 2021: 1-12. [CrossRef]

[35] Borges RC, Hohmann MS, Borghi SM. Dendritic cells in COVID-19 immunopathogenesis: insights for a possible role in determining disease outcome. Int Rev Immunol. 2021; 40(1-2): 108-125. [CrossRef]

[36] Bertram S, Heurich A, Lavender H, Gierer S, Danisch S, Perin P, Lucas JM, Nelson PS, Pöhlmann S, Soilleux EJ. 
Influenza and SARS-coronavirus activating proteases TMPRSS2 and HAT are expressed at multiple sites in human respiratory and gastrointestinal tracts. PLoS One. 2012; 7(4): 1-8. [CrossRef].

[37] Rouse BT, Sehrawat S. Immunity and immunopathology to viruses: what decides the outcome? Nat RevImmunol.2010; 10: 514-526. [CrossRef]

[38] Cervantes-Barragan L, Züst R, Weber F, Spiegel M, Lang KS, Akira S, Thiel V, Ludewig B. Control of coronavirus infection through plasmacytoid dendritic-cell-derived type I interferon. Blood. 2007; 109(3): 1131-1137. [CrossRef]

[39] Schmitz ML, Kracht M, Saul VV. The intricate interplay between RNA viruses and NF-kB. Biochimica et Biophysica Acta. 2014; 1843(11): 2754-2764. [CrossRef]

[40] Schneider WM, Chevillotte MD, Rice CM. Interferon-stimulated genes: a complex web of host defenses.Annu Rev Immunol. 2014; 32(1): 513-545. [CrossRef]

[41] ClinicalTrials.gov Phase I-II trial of dendritic cell vaccine to prevent COVID-19 in adults 2021.https://clinicaltrials.gov/ct2/show/NCT04386252,(accessed on 19 May 2021).

[42] van Riel D, de Wit E. Next-generation vaccine platforms for COVID-19. Nat Mater. 2020; 19: 810-812. [CrossRef]

[43] Saadeldin MK, Abdel-Aziz AK, Abdellatif A. Dendritic cell vaccine immunotherapy; the beginning of the end ofcancer and COVID-19. A hypothesis. Med Hypotheses. 2021; 146: 110365. [CrossRef]

This is an open access article which is publicly available on our journal's website under Institutional Repository at http://dspace.marmara.edu.tr. 